\title{
Statement
}

\section{당뇨병과 비타민D}

\section{홍준화}

을지대학교병원 내분비내과

\section{Diabetes and Vitamin D}

\section{Jun Hwa Hong}

Department of Internal Medicine, Eulji University Hospital, Daejeon, Korea

\begin{abstract}
Renewed interest in vitamin D has occurred recently because it has been linked to diabetes mellitus, cardiovascular disease, autoimmune disease, infection, and cancer. Research studies continue to support vitamin $\mathrm{D}$ deficiency as correlated with development of diabetes mellitus and progression of diabetes complications. However, most research is based on observational, epidemiological studies, which are important for generating hypotheses but do not prove causality. Furthermore, there is lack of evidence demonstrating the role of vitamin $\mathrm{D}$ supplementation in preventing diabetes from a prediabetic state or improving glycemic control and diabetes complications. The purpose of this article is to summarize the latest information related to diabetes and vitamin D.
\end{abstract}

Keywords: Diabetes complications; Diabetes mellitus; Prediabetic state; Vitamin D

$$
\text { 서론 }
$$

비타민D의 역할은 주로 칼슘의 흡수와 분포에 관여한다고 알려져 있어서, 골밀도 및 골다공증에 관한 연구가 많다. 그
렇지만 최근 연구에서는 체내의 많은 세포에서 비타민D 수용 체가 발견되면서 당뇨, 고혈압 및 심혈관 질환, 자가면역질환, 감염성 질환뿐만 아니라, 다양한 암종과의 연관성에 대한 연 구 결과들이 보고되고 있다. 비타민 $\mathrm{D}$ 는 다른 비타민과는 다 
르게 햇빛을 쬐면 체내에서 생성되는 특징을 가지고 있지만, 우리나라 사람들은 야외활동 시 햇빛에 노출되는 신체 부위 면적이 작아 결핍되기 쉬운 미량영양소이기도 하다. 질병관리 본부에 따르면 우리나라 성인 남녀 10명 중 9명이 비타민D 부족 상태다.

체내 비타민D 농도의 부족함 또는 충분함에 대해 일관 되게 합의된 기준은 없으나, 세계보건기구(World Health Organization)는 혈중 25-hydroxyvitamin D $\{25(\mathrm{OH}) \mathrm{D}\}$ 의 농도가 $20 \mathrm{ng} / \mathrm{mL}$ 보다 낮은 경우를 부족한 상태로 보았다. 또한 미국 Institute of Medicine (IOM)에서는 혈중 25(OH) $\mathrm{D}$ 의 농도가 $20 \mathrm{ng} / \mathrm{mL}$ 이상일 때 $97.5 \%$ 인구에서 필요량을 만족시키며, $12 \mathrm{ng} / \mathrm{mL}$ 이하인 경우 비타민D 결핍 증상이 나 타날 수 있다고 하였다. 체내 비타민D의 적정 농도는 일치된 기준은 없으나 대략 $25 \sim 80 \mathrm{ng} / \mathrm{mL}$ 로 알려져 있고 일반적으 로 혈중 25(OH)D의 농도가 $10 \mathrm{ng} / \mathrm{mL}$ 미만인 경우를 비타민 $\mathrm{D}$ 결핍 상태로, $20 \mathrm{ng} / \mathrm{mL}$ 미만인 경우를 비타민D 부족 상 태로, $30 \mathrm{ng} / \mathrm{mL}$ 보다 높은 경우를 비타민D 적정 상태로 평가 한다.

본 저자는 당뇨병에서의 비타민D의 역할과 관련하여, 당뇨 병 예방, 당뇨병환자에서 혈당에 미치는 영향, 당뇨병 미세혈 관 합병증 및 심혈관 합병증에서의 연관성에 대해 정리하고자 한다.

\section{본론}

\section{1. 비타민D의 당뇨병 예방 효과}

비타민D 결핍은 인슐린 저항성을 악화시키고 췌장의 베타 세포 기능을 감소시켜 당뇨병 발생을 증가시키는 위험 요인 으로 제시되고 있다[1]. 76,220명, 21개의 연구를 메타분석한 결과, 혈중 $25(\mathrm{OH}) \mathrm{D}$ 농도가 낮은 경우 당뇨병 발생이 증가 하여 당뇨병 발생의 위험 요인으로 제시되었고, 혈중 $25(\mathrm{OH})$ $\mathrm{D}$ 의 농도가 $4 \mathrm{ng} / \mathrm{mL}$ 씩 증가할수록 당뇨병 발생률은 $4 \%$ 정도 낮아진다고 하였다[2]. 단기적으로 당뇨병전단계 환자 및 초기 제 2 형 당뇨병환자에게 매일 2,000 IU $(50 \mu \mathrm{g})$ 의 비타
민D를 투여하였을 때에 인슐린 저항성에 차이는 나타나지 않 았으나, 인슐린 분비능을 반영하는 disposition index가 대조 군보다 유의하게 증가하는 결과를 보고하였다. 췌장 기능의 개선 효과는 비타민D 투여에 추가적으로 칼슘을 투여하는 것과는 무관하게 비타민 $\mathrm{D}$ 를 투여한 군에서 모두 유의하게 증가하였다. Disposition index는 비타민D 투여군에서 26\% 상승하였고, 대조군에서 $14 \%$ 감소하여, 전체적으로 비타민D 투여군에서 대조군 대비 $40 \%$ 의 상승을 나타냈다. 혈당 변화 에서는 비타민D 투여군에서 대조군 대비 공복혈당, 식후혈당, 당화혈색소의 증가를 둔화시키는 효과를 보여주었으나, 혈 당 감소 효과는 나타내지 못하였다[3]. 기전적으로 비타민D 섭취 후에 증가된 1,25 dihydroxyvitamin $\mathrm{D}\left\{1,25(\mathrm{OH})_{2} \mathrm{D}\right\}$ 가 직접적으로 인슐린 유전자 촉진자(promotor)의 전사를 활성 화하여 인슐린 합성과 분비를 자극하기도 하고[4], 간접적으 로 췌장의 베타 세포에서 칼슘 농도에 영향을 주어 칼슘 의 존성 인슐린 분비를 증가시킬 수 있다[5]. 하지만 16 주간의 효 과만으로 당뇨병의 발생을 예방할 수 있다는 근거는 부족하 다.

Pittas 등[6]은 장기적인 비타민D 투여에 따른 당뇨병 발생 예방 효과를 분석하여 2019년 NEJM (New England Journal of Medicine) 저널에 보고하였다. 당뇨병전단계 환자를 대 상으로, 혈중 25(OH)D 농도에 관계없이 매일 4,000 $\mathrm{UU}$ 의 비 타민 $\mathrm{D}$ 를 투여한 그룹과 투여하지 않은 대조군을 대상으 로, 당뇨병 발생에 차이가 날 때까지 연구를 진행하였다. 총 2,433 명의 당뇨병전단계 대상자(비타민D 그룹 1,211명, 대조 군 1,212 명)를 2.5년간 관찰하여 비타민D 투여군에서는 293 명(9.39 events/person-years), 대조군에서는 323명(10.66 events/person-years)이 당뇨병으로 진행하였다. 당뇨병 발 생의 위험도(hazard ratio)는 0.88 (95\% confidence interval, 0.75 1.02)로, 통계적으로 유의한 차이를 보이지는 못하였다 [6]. 비타민D를 투여한 그룹에서 24개월 뒤의 혈중 $25(\mathrm{OH}) \mathrm{D}$ 의 농도는 $54.3 \mathrm{ng} / \mathrm{mL}$, 대조군에서는 $28.8 \mathrm{ng} / \mathrm{mL}$ 로 차이가 났지만, 초기 혈중 $25(\mathrm{OH}) \mathrm{D}$ 농도는 각각 $27.7 \mathrm{ng} / \mathrm{mL}, 28.2$ $\mathrm{ng} / \mathrm{mL}$ 로 비교적 높은 상태의 대상자들이 참여하여, 당뇨병 발생의 고위험군인 비타민D 부족 대상자에서의 당뇨병 예방 
효과를 반영하지는 못하였다. 비타민D가 부족한 당뇨병전단 계 혹은 정상 혈당 환자에서의 비타민D 투여에 따른 당뇨병 예방 효과에 대한 추가적인 연구가 필요하다.

\section{2. 제2형 당뇨병환자에서 비타민 $\mathrm{D}$ 의 효과: 혈당 조절}

당뇨병의 예방 효능에서 언급된 바와 같이, 비타민 $D$ 는 췌장 의 베타 세포에서 인슐린 분비능을 증가시키는 역할뿐만 아 니라 근육과 간에서의 비타민D 수용체에 반응하여 인슐린 저 항성을 개선하는 효과도 나타낸다[7]. 간접적으로 글루타 치온의 농도를 증가시키면서, 산화스트레스를 감소시켜 염 증 반응을 감소시키는 효과도 나타낸다[8]. 이러한 기전적 인 효과를 바탕으로 당뇨병환자에서 비타민D가 혈당 조절 에 미치는 영향에 관한 다양한 임상이 진행되었다. 비타민D 를 투여한 모든 연구에서 일관되게 혈당을 개선시키지는 못 하였지만, 19 개의 무작위 임상연구를 메타분석한 결과에 따 르면 단기 투여에 의한 효과로 HbAlc 0.17\% (-0.29\%, $-0.05 \%)$ 감소, 인슐린 저항성 $15 \%$ 감소의 결과를 보고하였 다. 하지만 장기 투여에 의한 효과에서는 혈당, 인슐린 저항성 에 유의한 차이를 나타내지는 못하였다[9]. 비타민D 투여 용 량 및 다양한 임상 인자들을 포함하여 20개의 임상 연구를 메타분석한 결과에서도, 제2형 당뇨병환자에서 비타민D 투여 후에 인슐린 저항성 지표인 Homeostatic Model Assessment for Insulin Resistance (HOMA-IR)가 유의하게 감소하였으 나 공복 혈당 및 $\mathrm{HbAlc}$ 는 유의한 변화를 보이지는 않았다. 특히 비타민D 용량이 하루 2,000 IU 이상, 3개월 이내의 단기 투약 기간, 투약 전 혈중 25(OH)D 농도가 $20 \mathrm{ng} / \mathrm{mL}$ 이하, 비만하지 않은 경우, $\mathrm{HbAlc}<7 \%$ 로 혈당 조절이 양호한 경 우, 또한 아시아 및 중동의 대상자인 경우에는 비타민D 투여 후에 인슐린 저항성 개선의 효과가 두드러지게 나타났다[10].

\section{3. 제2형 당뇨병환자에서 비타민D의 효과: 미세혈관 합병증}

당뇨병성 신경병증 중에서 통증을 동반한 당뇨병성 신경병
증은 삶의 질 감소뿐만 아니라 당뇨발 발생의 위험 및 족부 절단의 위험요인으로 작용한다. 통증을 동반한 당뇨병성 신 경병증 발생의 위험 요인으로는 환자 연령, 당뇨 유병기간, 당 화혈색소 등이 제시되고 있지만, 낮은 혈중 비타민D 농도도 위험요인으로 제시되고 있다. 실험실적으로 비타민D의 결핍은 신경 성장인자인 neurotrophin의 낮은 농도와 연관되어 있고, 신경에서의 칼슘 조절에 영향을 미쳐, 신경 분화 및 신경 성장 과 기능에 영향을 줄 수 있다. 또한 통증의 역치를 낮추는 역 할을 하여 통증을 동반한 당뇨병성 신경병증 발생에도 밀접 한 관련성이 있다[11]. 제2형 당뇨병환자에서 당뇨병성 신경병 증의 발생과 혈중 비타민D 농도와의 관련성을 분석한 10 개의 논문을 메타분석한 결과, 혈중 비타민D 결핍은 당뇨병성 신 경병증의 위험요인임을 확인하였다. 위 연구의 분석에 사용한 10 개 연구의 당뇨병성 신경병증군의 혈중 비타민D 농도는 모 두 $15 \mathrm{ng} / \mathrm{mL}$ 이하였다. 특히 아시아인을 대상으로 진행한 연 구 결과를 분석한 결과, 비타민D 결핍을 동반한 제2형 당뇨 병환자에서 비타민D 결핍이 없는 환자와 비교 시에 당뇨병성 신경병증의 발생 위험이 1.22 배 높게 나타나 당뇨병성 신경병 증 예방에서 비타민D의 중요성에 대해 보고하였다[12]. 당뇨 병성 신경병증 환자를 대상으로 비타민D 투여에 대한 4개의 무작위 대조군 연구를 메타분석한 결과, 비타민D 투여가 당 뇨병성 통증 점수를 완화하는 결과를 보고하였으나, 신경 전 도 속도에 유의한 영향을 나타내지는 못하였다[13].

당뇨병성 망막병증은 비증식성 망막병증, 증식성 망막병증 으로 나눌 수 있다. 당뇨병성 망막병증 환자의 약 $18 \%$ 에서 증식성 망막병증을 동반하고 있으며, 향후 실명 등의 위험한 합병증으로 진행될 위험이 높다. 망막병증에서 비타민D의 영 향은 망막세포 내의 고혈당에 의해 발생한 활성화 산소를 감 소시키며, 염증반응을 감소시켜 세포사멸을 억제하였다. 또한 혈관 내피세포의 성장인자의 발현을 감소시켜 망막병증의 발 생을 억제할 수 있는 기전도 제시되고 있다[14]. 망막병증을 동반한 당뇨병환자에서 혈중 비타민D 농도는 유의하게 감소 되어 있고, 혈중 비타민D 농도와 망막병증의 중증도와 관련 성이 있어 혈중 비타민D의 농도는 망막병증이 없는 당뇨병군 (23.2 ng/mL), 비증식성 망막병증군 $(21.5 \mathrm{ng} / \mathrm{mL})$, 증식성 망 
막병증군 $(18.0 \mathrm{ng} / \mathrm{mL})$ 에서 유의한 차이가 있다[15]. Nadri 등 [16]은 혈중 비타민D의 농도가 $18.6 \mathrm{ng} / \mathrm{mL}$ 이하로 낮은 요 인이 당뇨병성 망막병증 환자 중에서 증식성 망막병증을 감 별할 수 있는 바이오마커가 될 수 있다는 가능성을 보고하였 다. 비타민D 결핍과 망막병증의 유병률과는 많은 연구가 진 행되었으나 비타민D 보충 요법에 따른 망막병증의 예방 및 개선 효과에 대한 대규모 임상 연구는 부족하여 향후 추가 연구가 필요하다.

당뇨병성 신증은 말기신장질환의 가장 대표적인 병인으로 작용하며, 적극적인 혈당 조절에도 불구하고 지속적으로 유 병률이 증가하고 있으며 국내에서도 남성 당뇨병환자 10,000 명당 2006년 90명에서 2015년 117명으로, 여성 당뇨병환자 10,000명당 2006년 73명에서 2015년 100명으로 증가하고 있 다. 이에 따른 말기신장질환의 유병률도 증가하고 있으며, 심 혈관 질환 및 사망률과도 밀접한 관련성에 대해서는 잘 알려 져 있다. 당뇨병환자에서 당뇨병성 신증 예방의 중요성이 더 욱 중요한 이유이다. 당뇨병성 신증에서 비타민 $\mathrm{D}$ 는 renin 의 합성을 억제하여 RAS 억제제와 유사한 역할이 보고되었 고[17], 사구체 기저막에 영향을 주는 염증 인자들인 TGF$\beta, \mathrm{MCP}-1$, hepatocyte growth factor, thrombospondin-1, plasminogen activator inhibitor를 감소시키는 역할도 보고 되었다[18]. 비타민D의 신장 보호 효과를 기대할 수 있는 결 과이지만 신장 질환 자체가 비타민D 활성화 형태로의 이화과 정을 감소시키고 비타민D 결합 단백인 cubulin과 비타민D 항 상성을 조절하는 megalin의 신장 배설을 증가시켜[19] 혈중 비타민D 농도를 감소시키기에, 신장질환에 대한 인과관계가 명확하게 규명되지 않았다.

제2형 당뇨병환자를 대상으로 혈중 비타민D 농도와 미세 단백뇨(urine albumin to creatinine ratio > $30 \mu \mathrm{g} / \mathrm{mg}$ )를 동 반한 신병증의 위험도 관련성에 대한 6개 임상 연구를 메타분 석한 결과, 혈중 $25(\mathrm{OH}) \mathrm{D}<20 \mathrm{ng} / \mathrm{mL}$ 의 환자에서 신병증의 위험도는 1.8 배 높았다. 하지만 당뇨병성 신증 환자에서 비타 민D를 복용한 6개의 임상 연구를 메타분석한 결과, 단백뇨 감소 등의 효과는 유의하게 나타나지 않았다[20]. de Boer 등[21]은 약 700 명의 제 2 형 당뇨병환자에게 매일 2,000 IU의
비타민D를 투여하여 5년간 관찰하였으나 대조군 대비 사구 체여과율의 변화에 대해서는 유의한 차이를 보이지 못하였다. 비타민D 투여에 따른 요로 결석의 위험이 증가하는 부작용 은 나타나지 않았으나 정상 신기능을 보이는 제2형 당뇨병 환자에게 신증 예방을 위한 비타민D 투여에 대해서는 근거가 부족함을 입증하였다. 추가적으로 신장 질환의 상태 및 다양 한 비타민D 투여 용량에 따른 추가 임상 연구가 필요하다.

\section{4. 제2형 당뇨병환자에서 비타민D의 효과: 대혈관 합병증}

당뇨병환자에서 비타민D 투여에 따른 심혈관 질환 및 사 망률에 대한 대규모 연구결과는 아직까지 발표된 바는 없다. 2017년 Farrokhian 등[22]은 심혈관 질환을 동반한 제2형 당 뇨병환자 중 혈중 $25(\mathrm{OH}) \mathrm{D}<20 \mathrm{ng} / \mathrm{mL}$ 인 60 명의 대상자 들에게, 2주마다 경구용 50,000 IU 비타민D를 6개월간 투여 한 후에 심혈관 위험인자들의 변화를 분석하였다. 6개월 후 의 $25(\mathrm{OH}) \mathrm{D}$ 는 $34.5 \mathrm{ng} / \mathrm{mL}$ 로 증가하였고, hs-CRP (high sensitive C-reactive protein)는 유의하게 감소하였으며, 혈 중 nitric oxide, glutathione 농도는 유의하게 증가하였다. 추가적으로 혈당 및 인슐린 저항성도 감소하여 심혈관 질환 을 동반한 제 2 형 당뇨병환자에서 비타민D 투여에 의한 심혈 관 보호 효과를 기대할 수 있는 결과를 보여주었다. 하지만 당뇨병환자가 아닌 심혈관 질환 대상자들에 대한 비타민D 투 여 연구에서는 심혈관 위험 요인의 유의한 변화가 나타나지 않았다[23].

\section{결 론}

비타민D는 당뇨병환자에서 뼈에 대한 영향뿐만 아니라 당 대사 및 다양한 당뇨병 합병증에 연관성이 있음을 확인할 수 있다. 하지만 그 효과가 비타민D 투여만으로 일관되게 나타 나지는 못하고 있다. 특히 대상자들의 비타민D 결핍 상태는 혈당 악화 및 당뇨병성 합병증의 위험성을 높이는 연관성은 비교적 일관되게 나타난다. 하지만 비타민D 투여로 인하여, 
당 대사 및 당뇨병성 합병증을 예방할 수 있는 효과에 대한 근거는 아직은 부족한 상태이다. 투여 전의 혈중 $25(\mathrm{OH}) \mathrm{D}$ 의 농도, 투여 용량 및 투여 기간 등에 대한 추가적인 연구가 필 요하다. 중요한 것은 당뇨병으로 진행 위험이 높은 대상자나 당뇨병을 동반한 환자에서 비타민D 결핍 유무에 대한 확인이 필요하며, 비타민D 결핍 상태를 극복하기 위하여 비타민D 투 약뿐만 아니라 안전한 야외 활동을 권장하거나 식이 상태를 점검하는 관심을 가져야 할 필요가 있다.

\section{FUNDING}

This work was supported by Biomedical Research Institute grant, Kyungpook National University Hospital (2014)

\section{REFERENCES}

1. Kayaniyil S, Vieth R, Retnakaran R, Knight JA, Qi Y, Gerstein $\mathrm{HC}$, et al. Association of vitamin D with insulin resistance and beta-cell dysfunction in subjects at risk for type 2 diabetes. Diabetes Care 2010;33:1379-81.

2. Song Y, Wang L, Pittas AG, Del Gobbo LC, Zhang C, Manson JE, et al. Blood 25-hydroxy vitamin D levels and incident type 2 diabetes: a meta-analysis of prospective studies. Diabetes Care 2013;36:1422-8.

3. Mitri J, Dawson-Hughes B, Hu FB, Pittas AG. Effects of vitamin $\mathrm{D}$ and calcium supplementation on pancreatic $\beta$ cell function, insulin sensitivity, and glycemia in adults at high risk of diabetes: the Calcium and Vitamin D for Diabetes Mellitus (CaDDM) randomized controlled trial. Am J Clin Nutr 2011;94:486-94.

4. Maestro B, Molero S, Bajo S, Dávila N, Calle C. Transcriptional activation of the human insulin receptor gene by 1,25-dihydroxyvitamin $\mathrm{D}(3)$. Cell Biochem Funct 2002;20:227-32.
5. Sergeev IN, Rhoten WB. 1,25-Dihydroxyvitamin D3 evokes oscillations of intracellular calcium in a pancreatic beta-cell line. Endocrinology 1995;136:2852-61.

6. Pittas AG, Dawson-Hughes B, Sheehan P, Ware JH, Knowler WC, Aroda VR, et al. Vitamin D supplementation and prevention of type 2 diabetes. N Engl J Med 2019;381:520-30.

7. Zhou QG, Hou FF, Guo ZJ, Liang M, Wang GB, Zhang X. 1,25-Dihydroxyvitamin D improved the free fattyacid-induced insulin resistance in cultured $\mathrm{C} 2 \mathrm{C} 12$ cells. Diabetes Metab Res Rev 2008;24:459-64.

8. Saif-Elnasr M, Ibrahim IM, Alkady MM. Role of vitamin D on glycemic control and oxidative stress in type 2 diabetes mellitus. J Res Med Sci 2017;22:22.

9. Hu Z, Chen J, Sun X, Wang L, Wang A. Efficacy of vitamin D supplementation on glycemic control in type 2 diabetes patients: a meta-analysis of interventional studies. Medicine (Baltimore) 2019;98:e14970.

10. Li X, Liu Y, Zheng Y, Wang P, Zhang Y. The effect of vitamin D supplementation on glycemic control in type 2 diabetes patients: a systematic review and meta-analysis. Nutrients 2018;10:375.

11. Riaz S, Malcangio M, Miller M, Tomlinson DR. A vitamin $\mathrm{D}$ (3) derivative (CB1093) induces nerve growth factor and prevents neurotrophic deficits in streptozotocindiabetic rats. Diabetologia 1999;42:1308-13.

12. Qu GB, Wang LL, Tang X, Wu W, Sun YH. The association between vitamin $\mathrm{D}$ level and diabetic peripheral neuropathy in patients with type 2 diabetes mellitus: an update systematic review and meta-analysis. J Clin Transl Endocrinol 2017;9:25-31.

13. Yammine K, Wehbe R, Assi C. A systematic review on the efficacy of vitamin D supplementation on diabetic peripheral neuropathy. Clin Nutr 2020;39:2970-4.

14. Lu L, Lu Q, Chen W, Li J, Li C, Zheng Z. Vitamin D(3) 
protects against diabetic retinopathy by inhibiting high-glucose-induced activation of the ROS/TXNIP/ NLRP3 inflammasome pathway. J Diabetes Res 2018;2018:8193523.

15. Payne JF, Ray R, Watson DG, Delille C, Rimler E, Cleveland J, et al. Vitamin D insufficiency in diabetic retinopathy. Endocr Pract 2012;18:185-93.

16. Nadri G, Saxena S, Mahdi AA, Kaur A, Ahmad MK, Garg $\mathrm{P}$, et al. Serum vitamin D is a biomolecular biomarker for proliferative diabetic retinopathy. Int J Retina Vitreous 2019;5:31.

17. Li YC, Qiao G, Uskokovic M, Xiang W, Zheng W, Kong J. Vitamin D: a negative endocrine regulator of the reninangiotensin system and blood pressure. J Steroid Biochem Mol Biol 2004;89-90:387-92.

18. Li Y, Spataro BC, Yang J, Dai C, Liu Y. 1,25-dihydroxyvitamin $\mathrm{D}$ inhibits renal interstitial myofibroblast activation by inducing hepatocyte growth factor expression. Kidney Int 2005;68:1500-10.

19. Thrailkill KM, Jo CH, Cockrell GE, Moreau CS, Fowlkes JL. Enhanced excretion of vitamin D binding protein in type 1 diabetes: a role in vitamin $\mathrm{D}$ deficiency? J Clin Endocrinol Metab 2011;96:142-9.

20. Derakhshanian H, Shab-Bidar S, Speakman JR, Nadimi H, Djafarian K. Vitamin D and diabetic nephropathy: a systematic review and meta-analysis. Nutrition 2015;31:1189-94.

21. de Boer IH, Zelnick LR, Ruzinski J, Friedenberg G, Duszlak J, Bubes VY, et al. Effect of vitamin D and omega-3 fatty acid supplementation on kidney function in patients with type 2 diabetes: a randomized clinical trial. JAMA 2019;322:1899-909.

22. Farrokhian A, Raygan F, Bahmani F, Talari HR, Esfandiari R, Esmaillzadeh A, et al. Long-term vitamin D supplementation affects metabolic status in vitamin D-deficient type 2 diabetic patients with coronary artery disease. J Nutr 2017;147:384-9.

23. Bahrami LS, Ranjbar G, Norouzy A, Arabi SM. Vitamin D supplementation effects on the clinical outcomes of patients with coronary artery disease: a systematic review and meta-analysis. Sci Rep 2020;10:12923. 